\title{
Seed Germination and Effects of Three Watering Regimes on the Growth of Dialium guineense (Wild) Seedlings
}

\author{
0. Olajide' , A. A. Oyedeji ${ }^{2,3 *}$, G. S. Tom¹, J. Kayode ${ }^{4}$ \\ ${ }^{1}$ Department of Forestry and Wildlife, Faculty of Agriculture, University of Uyo, Uyo, Nigeria \\ ${ }^{2}$ Plant Science Unit, Department of Biological Sciences, Niger Delta University, Wilberforce Island, Bayelsa State, \\ Nigeria \\ ${ }^{3}$ Department of Environmental and Analytical Sciences, Faculty of Science and Engineering, University of \\ Wolverhampton, Wolverhampron, UK \\ ${ }^{4}$ Department of Plant Science, Faculty of Science, Ekiti State University, Ado-Ekiti, Nigeria \\ Email: solaolajide1967@gmail.com, ${ }^{*}$ ayodele.ovedeji@yahoo.com
}

Received 19 July 2014; revised 21 August 2014; accepted 11 September 2014

Copyright $@ 2014$ by authors and Scientific Research Publishing Inc.

This work is licensed under the Creative Commons Attribution International License (CC BY).

http://creativecommons.org/licenses/by/4.0/

(c) (i) Open Access

\begin{abstract}
The effectiveness of three pre-germination treatments in breaking dormancy of the seeds of Dialum guineense and effects of three watering regimes on the growth performance of the seedlings were investigated. The pre-germination treatments were: soaking in hot water for 10 seconds and cooling down in cold water $\left(T_{1}\right)$, soaking in cold water for 24 hours $\left(T_{2}\right)$, soaking in running water for 48 hours $\left(T_{3}\right)$ and control $\left(T_{4}\right)$, while watering regimes include: watering once daily in the morning $\left(W_{1}\right)$, watering once every two days in the morning $\left(W_{2}\right)$ and watering once every three days in the morning $\left(W_{3}\right)$. The results showed that germination occurred first at 5 days after sowing (5 DAS) among the seeds soaked in cold water for 24 hours before sowing $\left(\mathrm{T}_{2}\right)$, while the untreated seeds (control) took the longest period of 12 days before germination occurred. $T_{1}$ had the highest germination value of $49.6 \%$ while $T_{3}$ had the least of $31.2 \%$. The effects of watering regimes were found to be significantly different on stem-collar diameter, leaf area and total dry weight $(P<0.05)$. The least significant difference (LSD) test showed that $W_{2}$ and $W_{3}$ supported the best growth performance. It is concluded from the results that $T_{2}$ should be adopted for breaking the dormancy of Dialium guineense seeds and watering interval of three days would not dispose the seedlings to water-stress.
\end{abstract}

\section{Keywords}

Dialium guineense, Seeds, Dormancy, Pre-Germination, Seedlings Growth, Watering Regimes

\footnotetext{
${ }^{*}$ Corresponding author.
}

How to cite this paper: Olajide, O., Oyedeji, A.A., Tom, G.S. and Kayode, J. (2014) Seed Germination and Effects of Three Watering Regimes on the Growth of Dialium guineense (Wild) Seedlings. American Journal of Plant Sciences, 5, 3049-3059. 


\section{Introduction}

The benefits of forest in the provision of arrays of products and services of great importance to man's survival and balanced development have been recognized. Natural forests, particularly in the tropical region, are complex ecosystem. They have great diversity of tree species with different uses. One of the fundamental and indispensable needs of man provided by forests is food. This is the benefits that have been ignored in the past and are currently being eroded as forests in many parts of the world are cleared and the remaining trees on farmlands come under increasing pressure [1].

Tropical rainforests are stocked with many tree species that produce copious edible, highly nutritious and medicinal fruits, seeds, leaves, twigs nuts and bark which are of socio-economic importance [2]. However, the rapidity of erosion of genetic resources occasioned by seemingly unmitigated deforestation is alarming. Attempts are being made to conserve these tree species, but these have been difficult to achieve because of paucity of information on their ecology and silviculture. Thus, the potentials of the trees have virtually not been improved, and many of them are on the verge of extinction. The essential ecological and silvicultural information needed on the trees includes flowering and fruiting patterns, seed germination and growth requirement to facilitate domestication and improvement of their potentials.

The current research is therefore, designed to investigate the germination of the seeds and seedlings growth of Dialium guineense in response to different watering regimes. Dialium guineense, commonly called Black Velvet Tamarind, is a small size tree of rainforest that produces seeds, which have edible and nutritious outer-coat. It belongs to the family Caesalpinaceae. The seeds are available in the dry season and widely sold in markets in Southeastern Nigeria. It is popularly referred to as "Vitamin C seed". It is hoped that the information gathered would help conservation and domestication of the tree species.

\section{Materials and Methods}

\subsection{Seed Collection}

Matured and uninjured ripe fruits of Dialium guineense were collected from the southeastern belt of Nigerian rainforest. The fruits were depulped and their seeds extracted mechanically.

\subsection{Seed Germination}

A total of one thousand (1000) seeds were used for the germination experiment. Two hundred and fifty (250) seeds each were given the following pre-germination treatments:

1) Soaking in hot water for 10 seconds and cooling down in cold water for one hour $\left(\mathbf{T}_{\mathbf{1}}\right)$.

2) Soaking in cold water for 24 hours $\left(\mathbf{T}_{2}\right)$.

3) Soaking in running water for 48 hours $\left(\mathbf{T}_{3}\right)$.

4) Untreated seeds or control $\left(\mathbf{T}_{4}\right)$.

All the seeds were sown on the same day on separate germination boxes filled with topsoil from forest floor by broadcasting method. Each germination box measured $90 \mathrm{~cm} \times 70 \mathrm{~cm} \times 7.5 \mathrm{~cm}$. Watering was done daily in the morning in an over-head shade nursery. Germination counts were taken daily and spanned for five weeks from the first day germination was observed.

\subsection{Growth Assessment}

One hundred and eighty (180) sturdy seedlings at four leaf stage were transplanted from germination boxes into polypots filled with topsoil collected from forest floor. The physicochemical parameters of the topsoil are as follows: base saturation (77.23\%), sand (87.20\%), silt (5.60\%), clay (7.20\%), pH (6.47), exchangeable cation (0.14), organic matter (3.11\%), total nitrogen (0.16\%), available phosphorus $\left(29.33 \mathrm{mg} / \mathrm{kg}^{-1}\right)$ and exchangeable bases $(7.73 \mathrm{cmol} / \mathrm{kg})$. Sixty (60) seedlings each in three replicates of twenty (20) seedlings per replicate were subject to the following watering regimes:

1) Watered once daily in the morning $\left(\mathbf{W}_{\mathbf{1}}\right)$.

2) Watered once every two days in the morning $\left(\mathbf{W}_{2}\right)$.

3) Watered once every three days in the morning $\left(\mathbf{W}_{3}\right)$.

The seedlings were arranged in a completely randomized design in a glass overhead shade nursery. The seedlings were assessed for growth performance three months after transplanting. The growth parameters as- 
sessed include shoot height, stem collar-diameter, leaf number, leaf area and total dry weight (biomass). Seedling height and stem collar diameter were measured with metre rule and Vanier Caliper respectively. Leaf number was assessed by physical counting and total leaf area of each seedling was determined by using the grid method. The total dry weight was assessed by carefully uprooting each seedling and then separated into shoot and root components. The root and shoot components of each seedling were oven-dried to constant weight at $80^{\circ} \mathrm{C}$ to determine the biomass.

\subsection{Data Analysis}

Percentage germination was calculated for each pre-germination treated and non-treated seeds. The mean of each growth parameter was calculated for each of the three categories of seedlings. The growth parameters data were subjected to analysis of variance (ANOVA). The means of the significantly different growth parameters were separated using least significant difference (LSD) test [3].

\section{Results}

The first germination was recorded at 5 DAS from the seeds soaked in cold water for 24 hours $\left(\mathbf{T}_{2}\right)$. The seeds soaked in hot water for 10 seconds $\left(\mathbf{T}_{\mathbf{1}}\right)$ had its first germination 6 DAS while the seeds soaked in cold water for 48hours $\left(\mathbf{T}_{3}\right)$ and non-treated seeds $\left(\mathbf{T}_{\mathbf{4}}\right)$ recorded their first germination 7 and 12 DAS respectively. $\mathbf{T}_{\mathbf{1}}$ had the highest germination value of $49.6 \%$, while $\mathbf{T}_{3}$ had the least of $31.2 \%$ (Table 1 ).

The seedlings watered once every three days $\left(\mathbf{W}_{3}\right)$ had the highest mean shoot height of $10.41 \mathrm{~cm}$ while those watered once every two days $\left(\mathbf{W}_{\mathbf{2}}\right)$ had $9.22 \mathrm{~cm}$ and the once watered everyday $\left(\mathbf{W}_{\mathbf{1}}\right)$ had $9.03 \mathrm{~cm}$. The analysis of variance (ANOVA) showed that there was no significant difference $(P>0.05)$ between the effects of the watering regimes on the height growth of the seedlings. Seedlings subjected to $\mathbf{W}_{3}$ had the highest mean stem-collar diameter of $0.28 \mathrm{~cm}$ while those of $\mathbf{W}_{\mathbf{2}}$ had the least mean stem-collar diameter of $0.26 \mathrm{~cm}$. $\mathbf{W}_{\mathbf{1}}$ seedlings had $0.27 \mathrm{~cm}$ as mean stem-collar diameter. The ANOVA of the stem-collar diameters shows that there was a significant difference $(\mathrm{P}<0.05)$ between the effects of the watering regimes on the seedlings stem-collar diameters (Table 2). The stem-collar diameter data are presented in Appendix 1.

The least significant difference (LSD) Value of the stem-collar diameter was 0.0271 and it which revealed no difference between the means stem-collar diameters of $\mathbf{W}_{1}, \mathbf{W}_{2}$ and $\mathbf{W}_{3}$ seedlings. The highest mean leaf number of 11 was recorded by the seedlings watered once every three days $\left(\mathbf{W}_{3}\right)$, while the seedlings watered once every two days $\left(\mathbf{W}_{\mathbf{2}}\right)$ had the least number of 9 . The seedling watered once daily $\left(\mathbf{W}_{\mathbf{1}}\right)$ had the mean leaf number of 10 . The ANOVA of leaf number was not significant $(\mathrm{P}>0.05)$. The $\mathbf{W}_{3}$ seedlings had the highest mean leaf area of $152.44 \mathrm{~cm}^{2}$, while $\mathbf{W}_{\mathbf{2}}$ had $86.96 \mathrm{~cm}^{2}$ and $\mathbf{W}_{\mathbf{1}}$ had $81.91 \mathrm{~cm}^{2}$. The ANOVA of leaf area showed that there was a significant difference between the effects of the watering regimes on the seedlings' leaf areas (Table 3 ). The leaf area data are contained in Appendix 2.

The LSD value of leaf area was 28.13 which showed that there was no difference between the mean leaf number of $\mathbf{W}_{1}$ and $\mathbf{W}_{2}$ seedlings but there was difference between $\mathbf{W}_{1}$ and $\mathbf{W}_{3}$, and $\mathbf{W}_{2}$ and $\mathbf{W}_{3}$. The $\mathbf{W}_{3}$ seedlings had the highest mean total dry weight of $0.7192 \mathrm{~g}$, while $\mathbf{W}_{2}$ seedlings had $0.4220 \mathrm{~g}$ and $\mathbf{W}_{1}$ seedlings had the least of $0.3454 \mathrm{~g}$. The ANOVA of the total dry weight indicated that there was significant difference $(\mathrm{P}<$ 0.05) in the effects of the watering regimes on dry matter accumulation (Table 4). The total dry weights of individual seedlings are in Appendix 3.

The LSD value of total dry weight was 0.3586 , which indicated that difference only occurred between the means total dry weights of $\mathbf{W}_{1}$ and $\mathbf{W}_{3}$ seedlings.

\section{Discussion}

Most of the tropical forest trees' seeds have been found to exhibit dormancy which enable them to remain on the forest floor and in the topsoil for a long period of time until favourable conditions are available via natural or human perturbation of the forest to stimulate their germination [4] [5]. Therefore, it often takes a long time before germination commences if the seeds of the trees are sown without any pre-germination treatment to break their dormancy. Dormancy can be a result of a hard seed coat, which is impervious to water and aeration required to stimulate germination or presence of chemical inhibitor in the seed cotyledon [6] [7]. In this study, germination occurred first at 5 DAS from among the seeds soaked in cold water for 24 hours as against other 
Table 1. Effectiveness of pre-germination treatments on the seeds of Dialium guineense.

\begin{tabular}{ccccc}
\hline $\begin{array}{c}\text { Pre-germination } \\
\text { Treatment }\end{array}$ & $\begin{array}{c}\text { No. of seeds treated } \\
\text { and sown }\end{array}$ & $\begin{array}{c}\text { Days germination } \\
\text { occurred after sowing }\end{array}$ & $\begin{array}{c}\text { No of seeds } \\
\text { germinated }\end{array}$ & Germination\% \\
\hline $\mathbf{T}_{\mathbf{1}}$ & 250 & 6 & 124 & 49.6 \\
$\mathbf{T}_{\mathbf{2}}$ & 250 & 5 & 89 & 35.6 \\
$\mathbf{T}_{\mathbf{3}}$ & 250 & 7 & 78 & 31.2 \\
$\mathbf{T}_{\mathbf{4}}$ & 250 & 12 & 121 & 48.4 \\
\hline
\end{tabular}

Table 2. Analysis of variance of stem-collar diameters of Dialiun guineense seedling subjected to three watering regimes.

\begin{tabular}{ccccc}
\hline Source of variation & Degree of freedom & Sum of square & Mean of square & F-ratio \\
\hline WR & 2 & 0.10 & 0.05 & $125^{*}$ \\
Error & 57 & 0.2 & 0.0004 & \\
Total & 57 & 0.12 & & \\
\hline
\end{tabular}

*Significant; WR = watering regimes.

Table 3. Analysis of variance of leaf area of Dialium guineense seedlings subjected to three watering regimes.

\begin{tabular}{ccccc}
\hline Source of variation & Degree of freedom & Sum of square & Mean of square & F-ratio \\
\hline WR & 2 & 61920.45 & 30960.23 & $71.88^{*}$ \\
Error & 57 & 24551.98 & 430.74 & \\
Total & 59 & 86472.43 & & \\
\hline
\end{tabular}

*Significant; WR = watering regimes.

Table 4. ANOVA of total dry weight of Dialium guineense seedlings subjected to three watering regimes.

\begin{tabular}{ccccc}
\hline Source of variation & Degree of freedom & Sum of square & Mean of square & 0.78 \\
\hline WR & 2 & 1.56 & 0.07 \\
Error & 57 & 4.05 & \\
Total & 59 & 5.61 & \\
\hline
\end{tabular}

*Significant; WR = watering regimes.

pre-germination treatments with occurrences of first germination on sixth and seventh days and the non treated seeds on twelveth day after sowing. It was observed that the seeds of some Albizia species soaked in cold water for 24 hours started germinating four days ahead of other seeds subjected to different pre-germination treatments [8]. The findings of the present study also agree with [9] [10], that soaking the seeds of Teak (Tectona grandis) in cold water for between 24 hours and 48 hours was the cheapest and best pre-germination treatment that shortened the number of days naturally required for germination to occur in a sown seeds of Teak. It has been found that the seeds of Tetrapleura tetraptera (a rainforest tree) soaked in cold water over-night started germination before other seed lots subjected to different pre-germination treatments [11]. In the work of [12], it was observed that germination first occurred from the seeds of Pentaclethra macrophylla soaked in cold water overnight before sowing among other pre-germination methods used. The most effectiveness of breaking dormancy by soaking seeds in cold water for 24 hours in this study is probably due to the softening of the seed coat and draining off of any chemical inhibitor that might be present by water, thereby shortening the number of days that would naturally have required for the seeds to germinate. All the physiological processes in plants take place in water medium. Tree seedlings are generally raised during the dry season in the tropics for planting out shortly after the onset of the following rain season. In many places, water is a limiting factor for raising tree seedlings. The prudent use of water becomes imperative to ensure that the young trees are not subjected to water-stress. In this study, Dialium guineense seedlings watered once every three days in the morning had good growth performance, which agrees with the earlier study on Brachystegia eurycoma seedlings by [13]. It has also been found that frequent watering of the seedlings of some tropical rainforest tree species reduced their growth rates and encouraged damping-off [14] [15]. These findings may be due to the fact that frequent watering of the seedlings can impair good aeration for the seedlings roots, and therefore reduce their rate of growth. 


\section{Conclusion}

It can be concluded that soaking the seeds of $D$. guineense in cold water for about 24 hours is a cheap and most effective way to break its dormancy and watering of the seedlings once every three days in the morning will not dispose them to water-stress, but promote good growth.

\section{References}

[1] Olajide, O., Udo, E.S. and Otu, D.O. (2008) Diversity and Population of Timber Tree Species Producing Valuable Non-Timber Products in Two Tropical Rainforests in Cross River State, Nigeria. Journal of Agriculture and Social Sciences, 4, 65-68.

[2] Oni, O. and Gbadamosi, A.F. (1998) Progeny Variation in Seedlings of Dacryodes edulis (G. Din). Journal of Tropical Forest Resources, 14, 38-47.

[3] Ostle, B. (1974) Statistics in Research. 2nd Edition, The Iowa State University Press, Ames, 585 p.

[4] Whitmore, T.C. (1998) An Introduction to Tropical Rainforests. Oxford University Press, Oxford, 282 p.

[5] Turner, I.N. (2001) The Ecology of Trees in the Tropical Rainforest. Cambridge University Press, Cambridge, 298 p. http://dx.doi.org/10.1017/CBO9780511542206

[6] Nwoboshi, L.C. (1982) Tropical Silviculture: Principles and Techniques. Ibadan University Press, Ibadan, 333 p.

[7] Lamprecht, H. (1989) Silviculture in the Tropics. Eschborn, Germany, 296 p.

[8] Kanna, C.S., Sudhakara, K., Augustine, A. and Ashokan, P.K. (1996) Seed Dormancy and Pre-Treatments to Enhance Germination in Selected Albizia spp. Journal of Tropical Forest Science, 8, 369-380.

[9] Manonmani, V. and Vananagamudi, K. (2003) Studies on Enhancing Seed Germination and Seedling Vigour in Teak (Tectina grandis). Journal of Tropical Forest Science, 15, 51-58.

[10] Offiong, M.O., Udofia, S.I., Olajide, O. and Ufot, I.N. (2010) Comparative Study of Pre-Germination Treatments and Their Effects on the Growth of Tectona grandis (Linn. F) Seedlings. African Research Review, 4, 368-378.

[11] Onyekwelu, S.S.C. (1990) Germination Studies in Tetrapleura tetraptera. The International Tree Crops Journal, 6, 59-66. http://dx.doi.org/10.1080/01435698.1990.9752871

[12] Asomugha, V.U. (2002) Effects of Pre-Treatment and Soil Potting Mixture on Germination and Early Growth of Pentaclethra macrophylla. Dissertation, University of Uyo, Uyo, 76 p.

[13] Ikojo, H.A., Olajide, O. and Uwadinma, I.J. (2005) Effects of Soil Media and Watering Regimes on the Growth of Brachystegia evrycoma (HARNS) Seedlings. Journal of Sustainable Agriculture and the Environment, 7, 93-98.

[14] Oni, O. and Bada, S.O. (1991) Effects of Seed Size on Seedlings Vigour in Idigbo (Terminalia ivoreusis). Journal of Tropical Forest Science, 4, 215-229.

[15] Jimoh, S.O. and Okali, D.U. (1999) Variations in Fruit and Seed Characteristics and Germination of Tetrapleura tetraptera (Schum \& Thonn) Taub. from Different Sources in South-Western Nigeria. Journal of Tropical Forest Resources, 15, 10-21. 


\section{Appendix}

Appendix 1. The stem-collar diameter (cm) of Dialium guineense seedlings subjected to three watering regimes.

\begin{tabular}{|c|c|c|c|}
\hline $\mathrm{S} / \mathrm{N}$ & $\mathrm{W}_{1}$ Seedlings & $\mathrm{W}_{2}$ Seedlings & $\mathrm{W}_{3}$ Seedlings \\
\hline 1 & 0.26 & 0.22 & 0.23 \\
\hline 2 & 0.39 & 0.23 & 0.26 \\
\hline 3 & 0.26 & 0.15 & 0.27 \\
\hline 4 & 0.23 & 0.24 & 0.28 \\
\hline 5 & 0.25 & 0.27 & 0.28 \\
\hline 6 & 0.24 & 0.22 & 0.27 \\
\hline 7 & 0.26 & 0.23 & 0.32 \\
\hline 8 & 0.25 & 0.20 & 0.29 \\
\hline 9 & 0.28 & 0.28 & 0.26 \\
\hline 10 & 0.26 & 0.37 & 0.30 \\
\hline 11 & 0.30 & 0.32 & 0.38 \\
\hline 12 & 0.22 & 0.30 & 0.27 \\
\hline 13 & 0.24 & 0.25 & 0.32 \\
\hline 14 & 0.21 & 0.21 & 0.28 \\
\hline 15 & 0.30 & 0.27 & 0.26 \\
\hline 16 & 0.22 & 0.25 & 0.29 \\
\hline 17 & 0.28 & 0.29 & 0.31 \\
\hline 18 & 0.35 & 0.26 & 0.30 \\
\hline 19 & 0.22 & 0.30 & 0.37 \\
\hline 20 & 0.31 & 0.26 & 0.28 \\
\hline 21 & 0.26 & 0.22 & 0.23 \\
\hline 22 & 0.39 & 0.23 & 0.26 \\
\hline 23 & 0.26 & 0.15 & 0.27 \\
\hline 24 & 0.23 & 0.24 & 0.28 \\
\hline 25 & 0.25 & 0.27 & 0.28 \\
\hline 26 & 0.24 & 0.22 & 0.27 \\
\hline 27 & 0.26 & 0.23 & 0.32 \\
\hline 28 & 0.25 & 0.20 & 0.29 \\
\hline 29 & 0.28 & 0.28 & 0.26 \\
\hline 30 & 0.26 & 0.37 & 0.30 \\
\hline 31 & 0.30 & 0.32 & 0.38 \\
\hline 32 & 0.22 & 0.30 & 0.27 \\
\hline 33 & 0.24 & 0.25 & 0.32 \\
\hline 34 & 0.21 & 0.21 & 0.28 \\
\hline 35 & 0.30 & 0.27 & 0.26 \\
\hline 36 & 0.22 & 0.25 & 0.29 \\
\hline 37 & 0.28 & 0.29 & 0.31 \\
\hline 38 & 0.35 & 0.26 & 0.30 \\
\hline 39 & 0.22 & 0.30 & 0.37 \\
\hline 40 & 0.31 & 0.26 & 0.28 \\
\hline 41 & 0.26 & 0.22 & 0.23 \\
\hline 42 & 0.39 & 0.23 & 0.26 \\
\hline 43 & 0.26 & 0.15 & 0.27 \\
\hline 44 & 0.23 & 0.24 & 0.28 \\
\hline 45 & 0.25 & 0.27 & 0.28 \\
\hline
\end{tabular}


O. Olajide et al.

\begin{tabular}{lllll} 
Continued & \multicolumn{1}{l}{} & \\
\cline { 2 - 5 } & 46 & 0.24 & 0.22 & 0.27 \\
47 & 0.26 & 0.23 & 0.32 \\
48 & 0.25 & 0.20 & 0.29 \\
49 & 0.28 & 0.28 & 0.26 \\
50 & 0.26 & 0.37 & 0.30 \\
51 & 0.30 & 0.32 & 0.27 \\
52 & 0.22 & 0.30 & 0.32 \\
53 & 0.24 & 0.25 & 0.28 \\
54 & 0.21 & 0.21 & 0.26 \\
55 & 0.30 & 0.27 & 0.29 \\
56 & 0.22 & 0.25 & 0.31 \\
57 & 0.28 & 0.29 & 0.30 \\
58 & 0.35 & 0.26 & 0.37 \\
59 & 0.22 & 0.30 & 0.28
\end{tabular}


Appendix 2. The leaf area $\left(\mathrm{cm}^{2}\right)$ of $D$. guineense seedlings subjected to three watering regimes.

\begin{tabular}{|c|c|c|c|}
\hline $\mathrm{S} / \mathrm{N}$ & $\mathrm{W}_{1}$ Seedlings & $\mathrm{W}_{2}$ Seedlings & $\mathrm{W}_{3}$ Seedlings \\
\hline 1 & 101.33 & 86.00 & 133.20 \\
\hline 2 & 67.56 & 95.56 & 148.00 \\
\hline 3 & 67.56 & 76.44 & 148.00 \\
\hline 4 & 67.56 & 76.44 & 162.80 \\
\hline 5 & 92.89 & 86.00 & 133.20 \\
\hline 6 & 59.11 & 86.00 & 162.80 \\
\hline 7 & 67.56 & 76.44 & 177.60 \\
\hline 8 & 67.56 & 76.44 & 148.00 \\
\hline 9 & 84.44 & 76.44 & 207.20 \\
\hline 10 & 67.56 & 95.56 & 118.40 \\
\hline 11 & 92.89 & 133.78 & 133.20 \\
\hline 12 & 84.44 & 66.89 & 133.20 \\
\hline 13 & 76.00 & 95.56 & 162.80 \\
\hline 14 & 118.22 & 76.44 & 118.40 \\
\hline 15 & 92.89 & 66.89 & 148.00 \\
\hline 16 & 84.44 & 86.00 & 133.20 \\
\hline 17 & 84.44 & 105.11 & 133.20 \\
\hline 18 & 84.44 & 76.44 & 148.00 \\
\hline 19 & 92.89 & 95.56 & 236.80 \\
\hline 20 & 84.44 & 105.11 & 162.80 \\
\hline 21 & 101.33 & 86.00 & 133.20 \\
\hline 22 & 67.56 & 95.56 & 148.00 \\
\hline 23 & 67.56 & 76.44 & 148.00 \\
\hline 24 & 67.56 & 76.44 & 162.80 \\
\hline 25 & 92.89 & 86.00 & 133.20 \\
\hline 26 & 59.11 & 86.00 & 162.80 \\
\hline 27 & 67.56 & 76.44 & 177.60 \\
\hline 28 & 67.56 & 76.44 & 148.00 \\
\hline 29 & 84.44 & 76.44 & 207.20 \\
\hline 30 & 67.56 & 95.56 & 118.40 \\
\hline 31 & 92.89 & 133.78 & 133.20 \\
\hline 32 & 84.44 & 66.89 & 133.20 \\
\hline 33 & 76.00 & 95.56 & 162.80 \\
\hline 34 & 118.22 & 76.44 & 118.40 \\
\hline 35 & 92.89 & 66.89 & 148.00 \\
\hline 36 & 84.44 & 86.00 & 133.20 \\
\hline 37 & 84.44 & 105.11 & 133.20 \\
\hline 38 & 84.44 & 76.44 & 148.00 \\
\hline 39 & 92.89 & 95.56 & 236.80 \\
\hline 40 & 84.44 & 105.11 & 162.80 \\
\hline 41 & 101.33 & 86.00 & 133.20 \\
\hline 42 & 67.56 & 95.56 & 148.00 \\
\hline 43 & 67.56 & 76.44 & 148.00 \\
\hline 44 & 67.56 & 76.44 & 162.80 \\
\hline 45 & 92.89 & 86.00 & 133.20 \\
\hline 46 & 59.11 & 86.00 & 162.80 \\
\hline
\end{tabular}


O. Olajide et al.

\section{Continued}

\begin{tabular}{lccc}
\hline 47 & 67.56 & 76.44 & 177.60 \\
48 & 67.56 & 76.44 & 148.00 \\
49 & 84.44 & 76.44 & 207.20 \\
50 & 67.56 & 95.56 & 118.40 \\
51 & 92.89 & 133.78 & 133.20 \\
52 & 84.44 & 66.89 & 133.20 \\
53 & 76.00 & 95.56 & 162.80 \\
54 & 118.22 & 76.44 & 118.40 \\
55 & 92.89 & 66.89 & 148.00 \\
56 & 84.44 & 86.00 & 133.20 \\
57 & 84.44 & 105.11 & 133.20 \\
58 & 84.44 & 76.44 & 148.00 \\
59 & 92.89 & 95.56 & 236.80 \\
60 & 84.44 & 105.11 & 162.80 \\
\hline
\end{tabular}


Appendix 3. The total dry weight (g) of D. guineense seedlings subjected to three watering regimes.

\begin{tabular}{|c|c|c|c|}
\hline $\mathrm{S} / \mathrm{N}$ & $\mathrm{W}_{1}$ Seedlings & $\mathrm{W}_{2}$ Seedlings & $\mathrm{W}_{3}$ Seedlings \\
\hline 1 & 0.4685 & 0.549 & 0.0923 \\
\hline 2 & 0.2957 & 0.2411 & 0.5839 \\
\hline 3 & 0.6857 & 0.0089 & 0.6696 \\
\hline 4 & 0.3996 & 0.3811 & 0.4302 \\
\hline 5 & 0.3785 & 0.269 & 0.6512 \\
\hline 6 & 0.0835 & 0.2323 & 0.673 \\
\hline 7 & 0.0882 & 0.2137 & 0.8532 \\
\hline 8 & 0.3465 & 0.1467 & 0.7437 \\
\hline 9 & 0.4697 & 0.2614 & 0.9182 \\
\hline 10 & 0.3381 & 0.8675 & 0.3998 \\
\hline 11 & 0.2275 & 0.944 & 0.3325 \\
\hline 12 & 0.3421 & 0.6132 & 0.7619 \\
\hline 13 & 0.2464 & 0.3768 & 0.8158 \\
\hline 14 & 0.2763 & 0.3306 & 0.4589 \\
\hline 15 & 0.2251 & 0.2001 & 0.7565 \\
\hline 16 & 0.2251 & 0.3872 & 0.4747 \\
\hline 17 & 0.4399 & 0.8117 & 0.79 \\
\hline 18 & 0.4703 & 0.2061 & 0.9998 \\
\hline 19 & 0.2989 & 0.7989 & 1.5798 \\
\hline 20 & 0.6058 & 0.6011 & 1.399 \\
\hline 21 & 0.4685 & 0.549 & 0.0923 \\
\hline 22 & 0.2957 & 0.2411 & 0.5839 \\
\hline 23 & 0.6857 & 0.0089 & 0.6696 \\
\hline 24 & 0.3996 & 0.3811 & 0.4302 \\
\hline 25 & 0.3785 & 0.269 & 0.6512 \\
\hline 26 & 0.0835 & 0.2323 & 0.673 \\
\hline 27 & 0.0882 & 0.2137 & 0.8532 \\
\hline 28 & 0.3465 & 0.1467 & 0.7437 \\
\hline 29 & 0.4697 & 0.2614 & 0.9182 \\
\hline 30 & 0.3381 & 0.8675 & 0.3998 \\
\hline 31 & 0.2275 & 0.944 & 0.3325 \\
\hline 32 & 0.3421 & 0.6132 & 0.7619 \\
\hline 33 & 0.2464 & 0.3768 & 0.8158 \\
\hline 34 & 0.2763 & 0.3306 & 0.4589 \\
\hline 35 & 0.2251 & 0.2001 & 0.7565 \\
\hline 36 & 0.2251 & 0.3872 & 0.4747 \\
\hline 37 & 0.4399 & 0.8117 & 0.79 \\
\hline 38 & 0.4703 & 0.2061 & 0.9998 \\
\hline 39 & 0.2989 & 0.7989 & 1.5798 \\
\hline 40 & 0.6058 & 0.6011 & 1.399 \\
\hline 41 & 0.4685 & 0.549 & 0.0923 \\
\hline 42 & 0.2957 & 0.2411 & 0.5839 \\
\hline 43 & 0.6857 & 0.0089 & 0.6696 \\
\hline 44 & 0.3996 & 0.3811 & 0.4302 \\
\hline 45 & 0.3785 & 0.269 & 0.6512 \\
\hline 46 & 0.0835 & 0.2323 & 0.673 \\
\hline
\end{tabular}


O. Olajide et al.

\section{Continued}

\begin{tabular}{llcc}
\hline 47 & 0.0882 & 0.2137 & 0.8532 \\
48 & 0.3465 & 0.1467 & 0.7437 \\
49 & 0.4697 & 0.2614 & 0.9182 \\
50 & 0.3381 & 0.8675 & 0.3998 \\
51 & 0.2275 & 0.944 & 0.3325 \\
52 & 0.3421 & 0.6132 & 0.7619 \\
53 & 0.2464 & 0.3768 & 0.8158 \\
54 & 0.2763 & 0.3306 & 0.4589 \\
55 & 0.2251 & 0.2001 & 0.7565 \\
56 & 0.2251 & 0.3872 & 0.4747 \\
57 & 0.4399 & 0.8117 & 0.79 \\
58 & 0.4703 & 0.2061 & 0.9998 \\
59 & 0.2989 & 0.7989 & 1.5798 \\
60 & 0.6058 & 0.6011 & 1.399 \\
\hline
\end{tabular}


Scientific Research Publishing (SCIRP) is one of the largest Open Access journal publishers. It is currently publishing more than 200 open access, online, peer-reviewed journals covering a wide range of academic disciplines. SCIRP serves the worldwide academic communities and contributes to the progress and application of science with its publication.

Other selected journals from SCIRP are listed as below. Submit your manuscript to us via either submit@scirp.org or Online Submission Portal.
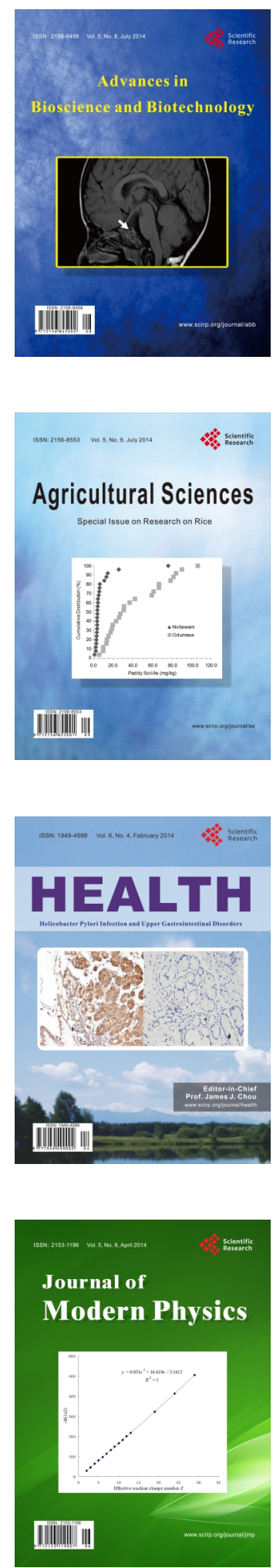
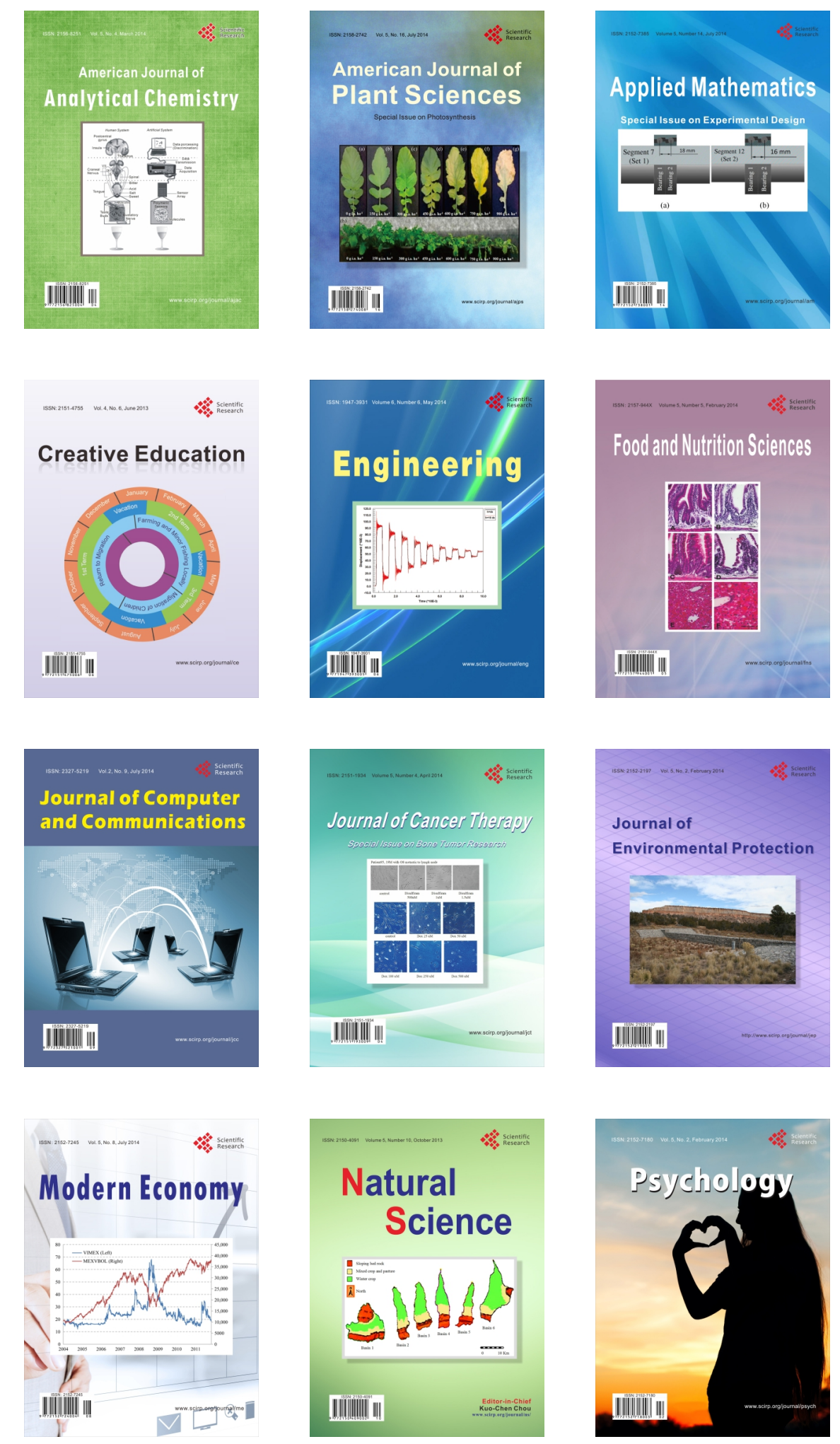